Volume: 1 | Number 1 | pp. 61 - 76

ISSN: 2633-352X (Print) | ISSN: 2633-3538 (Online) journals.tplondon.com/ijor

First Submitted: 15 July 2020 Accepted: 1 November 2020

DOI: https://doi.org/10.33182/ijor.v1i1.1229

\title{
A Religious Movement on Trial: Transformative Years, Judicial Questions and the Nation of Islam
}

\author{
Sultan Tepe ${ }^{1}$
}

\begin{abstract}
The Nation of Islam (NOI) is one of the most controversial political-religious groups in the United States. Some define it as an exclusionary race-based group, while others see it as a genuine empowerment movement. Although it has been viewed as an unconventional fringe group, NOI represents an important syncretic movement of its time. Its approach to Islam was marked by a range of currents from the anti-colonial interpretive framework of the Ahmadiyya to Marcus Garvey's Universal Negro Improvement Association forging a bighly dynamic narrative to explain the racial injustices and individual and collective requirements of future emancipation. Despite its strong anti-establishment discourse, NOI operates within the parameters legal and judicial system and seeks to reach out to new groups. As NOI faces the challenge of balancing its clashing inner currents rooted in its commitments to orthodox vs. vernacularized Islam or anti-systemic vs. accommodationist policies and often stigmatized by outside observers, it constitutes one of the most promising and precarious black movement.
\end{abstract}

Keywords: Nation of Islam; Islam; dissent; internal religious change; political-religious groups.

\section{Introduction}

The Nation of Islam (NOI or the Nation) is one of the most controversial political- religious groups in the United States. Some define it as an exclusionary race based group, while others see it as a genuine empowerment movement. ${ }^{2}$ Despite its critical role in US history, the ideas and identity of the Nation's founder, Wallace Fard, remain mostly a mystery - a mystery that is both embraced and reinforced by the movement's own theology. Likewise, despite continuing scholarly and popular interest, the movement's history and the details of its theology remain largely under-researched. This analysis contends that although it has been viewed as an unconventional fringe group, the Nation of Islam represents an important syncretic movement of its time. Understanding its theology, just like other theologies of resistance, requires a careful placement of its ideas into its historical and ideational context. Such contextualization enables us to recognize that the movement's approach to Islam is rooted in a range of currents from the anti-colonial interpretive framework of the Ahmaddiya branch of Islam to other African-American movements such as the Moorish Science Temple and Marcus Garvey's Universal Negro Improvement Association, among others. Each movement put forward its

\footnotetext{
${ }^{1}$ Sultan Tepe,PhD, Associate Professor, University of Illinois at Chicago, United States. E-mail: sultant@uic.edu
}

Acknowledgement: The author thanks the Institute for Research on Race \& Public Policy at the University of Illinois at Chicago for its support to this research. This analysis would not have been possible without Keith Simonds' meticulous assistance with archival research and careful review of the cited texts.

2 Attesting to its clashing images the Nation is praised by the Chicago Mayor's office led by Rahm Emanuel due to its contributions to community safety on the south side of Chicago but also listed as a hate group by the Southern Poverty Law Center. Armstrong Williams, “The Nation of Islam Could Be Chicago's Savior," The Hill, October 5, 2015. 
own distinct account to explain past injustices faced by those of African descent and offered narratives to explain their displacement as well as their future emancipation. ${ }^{3}$

Due to its multilayered theology and organizational model, both of which have been present since its inception, the Nation does not fit any easily into conventional social and religious categories. The movement has been assessed through some binaries (e.g., cult vs. religion, separatist vs. empowerment, colony vs. settlement) bringing the legitimacy of its ideas and practices into question. Being framed by such binaries strengthened the movement's appeal but also undermined its ability to operate. Below is the first analysis of a decisive court case (1977-1984) that sought to determine the rightful inheritors of the movement after the death of its second leader, Elijah Muhammad, in 1975. The analysis illustrates how those court deliberations captured the difficulties of demarcating different components of the movement, and that by doing so it inadvertently strengthened and legitimized the proponents of the more racialized and exclusionary tenets of the Nation of Islam. Due to the length of the trial, the "philosophical questions" the court felt compelled to address, and the emergence of the court as a main venue to settle distinct views among different parties within the movement, the final court decision played a crucial role in changing the internal dynamics of the movement. The types of questions and clashing answers draw our attention to why judicial processes cannot be seen as insulated. In fact, the ways in which social and popular questions surrounding the movement clearly madeinroads into the court's deliberations have reinforced the movement's image as a private organization. Despite its specific questions, the court's deliberation and decision also manifested the resiliency of markers that defined the movement's early years as an ambiguous organization with questionable practices.

The conclusions illustrate how the court case took place at a critical juncture and played a pivotal role in changing the internal dynamics of the movement. Eliciting its findings from the court's proceedings and presenting some of its documents for the first time, the analysis shows below that the case, in effect, put the movement on trial and sought to determine if the Nation was a familycentered profit-making venture, or a true religious movement. The review argues that the court case captures the continuities and shifts in the treatment of the Nation of Islam that has situated itself at the intersection of black civil rights and Islamic movements. As the following review of the movement highlights, the blending of distinct racial and religious claims makes the analysis of the movement highly complex. Precisely due to this hybrid appearance, the court's treatment of the Nation offers a unique vantage point to assess the ways in which exclusionary and inclusionary forces interact and thereby define the abilities of social movements and new theologies of resistance to carve out new arenas of contestation.

The following discussion (i) offers a brief intellectual background of the movement, (ii) places its emergence in its historical context and introduces the early terms applied to the Nation in popular and scholarly circles, (iii) describes the main issues faced in the court case, (iv) argues how the same tensions that led to the movement's success also triggered internal divisions and external interventions, and (v) how the court case captured a critical turning point in the internal organization and theologies of the movement which changed the course of its national and local trajectories and the way they were perceived by outsiders as well as the ways it reinforced the binaries (e.g., cult vs.

\footnotetext{
${ }^{3}$ Ahmadiyya Islam was founded in India by Mirza Ghulam Ahmad in the late 19th century. It is treated as an unorthodox branch of Islam and not recognized by many mainstream Islamic groups. Unlike other branches of Islam, perhaps due to its marginalization and new ideas, Ahmadiyyans consider spreading the main ideas of the movement as one of their main devotional commitments. For more see Walter, H. A. The Ahmadiya Movement. Oxford university press, 1918.
} 
religion, family- centered vs. social, empowerment vs. separatist etc.) that continue to simplify the movement's complex ideas and local and transnational engagements.

\section{Intellectual Background: Authentic Syncretism?}

The Nation was born in Detroit under the leadership of Wallace Fard whose identity and background remains largely unknown and contested. Some accounts refer to Fard's work in Detroit as early as 1929.4 A skillful salesman, Fard visited many houses to sell fabric and clothes and his "house meetings" became popular. Among the many topics he brought up for discussion, was why black Americans were mistreated in the US. His message resonated with many audiences, as Fard offered a broad historical explanation for the plight of the poor as well as for people's daily struggles in a rapidly changing country. Adopting conventional examples to better fit marginalized populations, Fard introduced new metaphors representing the African-American's experiences in the US as those of a dead-nation. A personal and spiritual awakening was needed to change the entire belief system (to abandon conventional religious beliefs and the "Poison book") and daily habits:

I can sit on top of the world and tell everyone that the most beautiful Nation is in the wilderness of North America. But do not let me catch any sister other than herself in regards to living the Life and weighing properly.

Big fields are awaiting for the wide Awake man to work out. Arise the Dead by the thousands!

The dead Nation must arise - for the Time is at hand. Look in your Poison Book.

Work cheerfully and fear not!

You are the Righteous, the Best and the Powerful. ${ }^{5}$

Beneath its revolutionary appearance, Fard's rich symbolic language was eerily similar to the traditional American rhetoric that emphasized mastering the land, controlling circumstances and even American exceptionalism. What changed the impact of Fard's teaching was Elijah Muhammad's participation with the movement. Elijah Muhammad (born Elijah Robert Poole), the son of a slave Baptist minister from Georgia, became the next, and most important, leader of the movement. Elijah's own experience of racial oppression in the South, familiarity with the Bible and with Garvey Marcus' teachings and experiences in Detroit (at that time the fourth largest urban center in the country) made him an excellent articulator of the movement's ideas. Although many accounts describe the movement as anachronistic and insular, a closer look at the Nation of Islam shows that it incorporated the tenets of various theologies and movements that marked the late 1800s and early 1900s:

- Wallace Fard and Ahmadiyya Islam--Very little is known about Elijah Muhammad's mentor and the founder of the Nation of Islam-Wallace Fard. However, the version of the Quran adopted by the movement suggests that he was familiar with, or perhaps even a follower of the Ahmadiyya branch of Islam, an unorthodox version

\footnotetext{
${ }^{4}$ Polk, A. R. "The Best Knower: Mythmaking, Fard Muhammad, and the Lost-Found Nation of Islam." International Journal of Religion \& Spirituality in Society, (10:1), 81-93, 2020.

${ }^{5}$ Elijah, Muhammad. (1957) The Supreme Wisdom: Solution To The So-Called Negroes Problem. Newport News, VA ; National Newport News.
} 
of Islam which was formed in Punjab, British India, near the end of the 19th century. The founder of Ahmadiyya Islam, Mirza Ghulam Ahmad, articulated an Islamic anti-colonial discourse. ${ }^{6}$

- The Moorish Science Temple of America--Prophet Noble Drew Ali founded the Moorish Science Temple of America, one of the most influential black movements in the early 1900s. Drew Ali (formerly known as Timothy Drew) identified himself as "Noble" Drew Ali, the divinely inspired messenger and a prophet who used Islamic idioms to present his ideas. Among others, Ali proclaimed that black populations, "so-called Negroes", in the US were in fact Moorish Americans, descended from the ancient Moabites and that they shared a rich heritage that stretched from ancient Palestine to Arabia and the Muslim empires in Eurasia and Africa. The movement emphasized the importance of recovering the authentic self (which, among other things, meant acquiring new last names) and economic selfsufficiency. With these goals in mind, he established a factory to produce oils, incense, soaps, and other Moorish products, the sales of which buoyed the religion's financial base. ${ }^{7}$

- The Universal Negro Improvement movement-- Marcus Garvey founded another one of the most impactful black movements in American history, the Universal Negro Improvement Association (UNIA) in the early 1900s. The UNIA aimed to foster worldwide unity among all blacks while rejecting any notion of integration in the US or beyond. Instead, the movement focused on the philosophy of black consciousness, self-help, and economic independence. Garvey's weekly newsletter, Negro World, became one of the most popular publications, with millions of followers, and his investments under the Black Star Line caused many controversies. ${ }^{8}$

- The Black Hebrew Movements-Some, like William Saunders Crowdy (1895), promoted a new theology that described the black populations in the US as the descendants of the twelve biblical tribes of Israel. For such theologies America's recently emancipated slaves were God's chosen people, the true Hebrews. They were part of a "theological élan to give a positive interpretation to the black past." ${ }^{9}$ In 1896 Crowdy was preaching on State Street in Chicago, gaining the nickname

${ }^{6}$ Jalal, A. (2005). Self And Sovereignty: Individual And Community In South Asian Islam Since 1850. London: Oxford University Press; Murphy, E. (2016). From Sufism to Ahmadiyya: a Muslim minority movement in South Asia. Contemporary South Asia, 24(2), 214215.

${ }^{7}$ Vardat, Scott J. 2013. "Drew Ali And The Moorish Science Temple Of America: A Minor Rhetoric Of Black Nationalism." Rhetoric \& Public Affairs 16, no. 4: 685-717; Mubashshir, Debra Washington. 2001. "Forgotten Fruit of the City: Chicago and the Moorish Science Temple of America." Cross Currents 51, no. 1: 6; Johnson, Sylvester A. 2010. "The Rise of Black Ethnics: The Ethnic Turn in African American Religions, 1916-1945." Religion \& American Culture 20, no. 2: 125-163; Nance, Susan. 2002. "Respectability and Representation: The Moorish Science Temple, Morocco, and Black Public Culture in 1920s Chicago." American Quarterly 54, no. 4: 623.

${ }^{8}$ Dagnini, Jérémie Kroubo. 2008. "Marcus Garvey: A Controversial Figure in the History of Pan- Africanism." Journal Of Pan African Studies 2, no. 3: 198-208; Carter, S 2002, 'TheEconomic Philosophy of Marcus Garvey', Western Journal Of Black Studies, 26, 1, p. 1; Negro with a Hat:The Rise and Fall of Marcus Garvey. By Colin Grant. Ox- ford: Oxford University Press, 2008.

9 Jones, Elias F. "Black Hebrews: The Quest for Authentic Identity." The Journal of Religious Thought, vol. 44, no. 2, 1988, pp. 35 
of "Black Elijah." This new genre of theologies identified the Blacks as morally and racially superior to others while projecting their inevitable full salvation. ${ }^{10}$

\section{Historical Context: "Dixie Exodus” and Racial Encounters}

As the above brief review indicates, the Nation of Islam was born in an ideational and theological environment where black movements focused on self-knowledge, which meant explaining past wrongs; the road to emancipation, which meant mapping out specific processes for salvation, and economic selfreliance which meant creating black-ownership centered economic activities; and political independence, which meant creating an independent nation free of any type of outside control or undue influence. Beyond the impact of the above listed theological and social movements, it is also important to note that the Nation's ideas were fermented during the influx of migrants from the south to the north to work in the booming war industries. ${ }^{11}$ In an effort to explain the race riots happening across the United States in industrial urban centers in the early decades of the 20th century, the Chicago Tribune presented the socially and religiously disruptive effect of the "Dixie Exodus" (or the Great Migration of 1916-1929 from the South to northern cities) and heightened social expectations as the most decisive determinants of racial clashes. The analyses reported an average of 1,000 people per month were leaving the south between 1937 and 1943. Sudden urbanization and the cultural impact of newly arrived rural whites who organized around religion created the context of the Nation of Islam's early years.

Although the population movement was important, what was also crucial was the increasing role of religion in organizing the migrants, particularly that with Southern-rural anti-Semitic tones. According to Dr. Claude C. Williams:

"Along with them [the rural southerners] came 2,500 'working preachers' who are now employed in Detroit's war plants. These men are the real leaders of the southern masses in Detroit. They preach, not because they are ordained, but because they feel 'the call' to preach. Every Sunday and often during the week they speak and they lead groups ranging from 20 or 25 to 300 or 500 persons." 12

Given the role of differing theologies in serving as the new organizational foundation for the large numbers of incoming migrants, the Nation's religious core was not an exception, but instead followed the pattern of the time. What made the Nation different from others was not its religious core, but the particular form of ideas it adopted and the level of success they found in institutionalizing its meetings and teachings. Diverging from the dominant Christian religious repertoire, the Nation instead turned to Islam.

Reflecting the confusion about, and reactions to the Nation's beliefs, one of the first scholarly assessments of the Nation published in 1938 described it as an African Voodoo Cult formed mostly by southern negro migrants who were relatively new arrivals to the industrial cities of the North. ${ }^{13}$ Despite its valuable data collection, the terms and presentation of this early publication reveal how the nation was delegitimized from its very inception. It was presented as a cult rooted in foreign

\footnotetext{
${ }^{10}$ Fauset, Arthur Huff. Black Gods of the Metropolis; Negro Religious Cults of the Urban North. New York: Octagon Books, 1974.

${ }^{11}$ Hughes, F. “Experts Trace Race Conflicts to Dixie Exodus,” The Chicago Tribune, (June 27, 1943).

12 ibid

${ }^{13}$ Erdmann Doane Beynon, “The Voodoo Cult Among Negro Migrants in Detroit,” American Journal of Sociology vol. 43 July 1937 - May 1938). Pp. 894-907
} 
cultures, a reincarnation of an African voodoo tradition, an uncivilized movement that was open to human sacrifice. References to other unacceptable acts (e.g., homeschooling with a teaching denouncing the dominant beliefs) put the movement firmly outside of the mainstream and questioned whether their existence was even compatible with civilization itself let alone an emerging urban life.

The Nation explained many social ills such as the illiteracy common among southern Negroes as an act of the devil. Elijah explained: "Why does the devil keep ourpeople illiterate? So that he can use them for a tool and also a slave. He keeps them blind to themselves so that he can master them."14 The movement's references to "devil" disturbed many observers, as the movement used this language to describe the white control of Black populations and the historical deployment of conventional Christian beliefs to enforce racial hierarchies. The exclusionary ideas of the Nation came to overshadow its other messages and thereby defined all of its distinct components. The analysis of the Nation often ended with a warning:

"The Black Muslims have become a protest group-more militant than the Urban league and the N.A.A.C.P. could ever dare to be-and, for this reason, often more appealing to the disgruntled Negro man on the street... Every negro protest organization today is, in its own way, impatient. Each is learning to seize the moral initiative. Each is preparing to force America to a showdown. And sooner or later, Americans will have to yield--if not to the soft spoken, reasonable demands of the conservative organizations, then to the strident, extreme, and vengeful demands of the black nationalists. For the moment--a brief and fateful moment--the choice is still in our hands."15

\section{Court Case: Who Owns the Movement?}

Elijah Muhammad's death in 1975 led to years of litigation attempting to resolve multiple questions surrounding the various issues of who would be the rightful heirs to numerous funds and bank accounts, which also forced the court to weigh various philosophical and religious questions. In the court's own words "The issue was to determine for whom or what was Elijah's poor Fund (the main account for which the movement's donations were solicited and collected). And was it Elijah Muhammad's personal fund or did it belong to the religion, the Nation of Islam?" The court case coincided with a time when the movement's internal questions had brought it to a crossroads as important as at any point in their history. Under the leadership of the movement's new leader Warith Deen Mohammed (the elected successor of the movement and the son of Elijah Muhammad who was originally named Wallace D. Muhammad), the Nation moved towards a more orthodox version of Islam and started to revisit some of the tenets of their race-centered rendition of Islam. ${ }^{16}$ While the movement's transition towards more mainstream Islam and gradual rejection of the categorical treatment of the white race as a singular group) was a welcome change for some; it also unsettled some members of the group who perceived the movement's emphasis on racial injustice as centrally important to its identity.

Sudden divergence from Wallace Fard and Elijah Muhammad's teachings, the critics argued, might conform the movement to an orthodox version of Islam but would undermine the movement's US

14 ibid

${ }^{15}$ Herb Nipson, “Astute Study of a hate group,” The Chicago Tribune, May 15, 1961.

${ }^{16}$ Warith Deen, The Lost-Found Nation, the Bilalian News, Vol.1, no.1 November 14, 1975. 
specific core and its historical mission. Amidst these disputes the court case served as an important platform to reflect internal theological discussions and steer the competition playing out within the movement. One might argue that Elijah Muhammad was responsible for this internal crisis as he left no will to specify the process for splitting his assets. However, Elijah left a certain amount to his rightful inheritors and the lack of a will might also indicate that he perceived the property as the movement's and not as his own. The situation was further complicated by the fact that in addition to his legitimate children, others also claimed to be his children and therefore rightful heirs. Over the years, Elijah's polygamous practices came under scrutiny and led to no small amount of controversy within the movement. Yet, the main question facing the court was whether the family of Elijah Muhammad had a right to the money, as an individual as opposed to the Nation of Islam itself.

The first trial ended in 1982. After four months, it had produced over 6,000 pages of testimony based on 16 witnesses, and Cook County Circuit Court Judge Henry Budzinski ruled to distribute Elijah's property, thus treating the Nation of Islam as a private organization and all Elijah's children as rightful inheritors. Although the estate was awarded \$4.6 million, the victory would be short lived. In 1984 the decision was reversed by the Illinois Appellate Court on appeal. The appeals court found that the funds and accounts in question were not clearly the property of Elijah Muhammad as an individual and that they may have belonged to the Nation of Islam as a religious organization. The central question had not been satisfactorily resolved. Judge Henry Budzinski heard the case again, with a new focus on the question of whether the money had been given to Elijah Muhammad the man or to the organization he led, the Nation of Islam. After four weeks and 1,500 pages of new testimony, Judge Budzinski ruled again that the property needed to be treated as personal not that of a movement.

The excerpts below exemplify how the court tried to distinguish different parts of the movement and clarify its identity:

Q: Are you here appearing sir pursuant to a subpoena? A: Yes, I am

Q: Did you Sir at any time have any contact with an organization known as the Nation of Islam?

Mr. Cook: I will object to the form of a question. There has been nothing in evidence to show the Nation of Islam is an organization?

Mr. Wilkins: I join in that objection.

The court: Sustained. Paraphrase the question counsel,

Mr. Lies: Are you familiar with the term Nation of Islam? A: Yes, I am

Q: When did you first hear that term?

A: I guess it's been many years: 1969, 1970

Q: There was a lot of publication about the mosque and I think it was referred to as the Nation of Islam at that time

A: Did you Sir, ever have any contact with persons purported to represent that organization? 
68 Transformative Years, Judicial Questions and the Nation of Islam

Mr. Cook: I will object to the form of a question; there's been no evidence showing the Nation of Islam is an organization.

Mr. Lies: Judge, the witness has just testified that he is aware of the Nation of Islam since the late 1960 s or the early 70 s and was familiar with the mosque.

The court: Correct. He is objecting to the term organization in relation to the Nation of Islam. I will sustain the objection. ${ }^{17}$

Similar discussions were not rare but instead dominated the trial and raised the question of whether or not the movement was religious, prompting some to object. When he was told the Nation was not a religion, a member of the NOI brought as a witness objected in the following way:

Rahman: Yes, I don't know understand what is going on. I thought I belonged to a religion. I believe in God.

The court: No comment ${ }^{18}$

In 1988, the Illinois Appellate Court would again reverse the ruling made in favor of the children. Even if the money had been given to Elijah Muhammad as an individual, the court concluded, this did not mean that it wasn't meant as a donation to the Nation of Islam. The brochures and orientation materials used by the Nation of Islam became important evidence. Those materials stressed that as a religious leader Elijah Muhammad collected charity and used the funds to help the poor and the needy. Yet the question was in what capacity Elijah collected the funds.

Mr. Joyce: So, Your Honor. If the words of the Honorable Elijah Muhammad can be brought into evidence as the leader of the mosque or the religion then certainly the words national secretary at that time of that...Religious organization or religion whatever can be brought into evidence to show what was said and what was the intention of the parties. Now this is prefatory to what will come later to lay a foundation work for the actions of the individual but still in all it's because of the relationship of Elijah Muhammad as the individual and as the leader of that religion. You can't say he is only an individual in this lawsuit but also the leader of the religion. So, what the officer say is also germane and should be a part of the record.

The court: Now we are getting into the philosophical issues

Mr. Joyce: No, I am getting into the law of agency. I'm getting into the status of parties and the law of agency and binding of the agency. We intend to set up a groundwork for the action of this witness and what he actually did as the basis of ... he did and that is the sole purpose for which it is being offered. Even so John Ali being the national secretary of that religion of the Nation of Islam and the mosque, being No.2., even without that purpose it would still be admitted into evidence to assist this court in showing what is the ultimate issue in this case or what is the ultimate decision in this case and that hang up because Mr. Ali is

\footnotetext{
${ }^{17}$ From the proceeding of the court case, Estate of Muhammed, 463 N.E.2d 732 (Ill. App. Ct. 1984) Mar 22, 1984

$18 \mathrm{ibid}$
} 
not here or it is hearsay we submit that is not true. The fact of the matter is what is the ultimate issue in this case, what does it bear on? ${ }^{19}$

The court argued that even if the money was also used by Elijah Muhammad and his family, this did not mean that the money was properly considered as personal gifts rather than religious or charitable donations. The court also noted that in the materials used to ask for donations, it told possible donors that their donations were income tax deductible, which would only be true if they were not contributions made to an individual.

Despite the evidence, the prolonged court case resulted in the distribution of the Nation of Islam properties between its two branches Warith Deen Mohammed (i.e., universal orthodox Islamcentered aspect of the movement) and the Farrakhan (i.e., race-centered aspect) side of the movement. While Deen lost most of the properties, Farrakhan reclaimed some of the main properties such as the movement's current headquarters, Mosque Maryam, thus ensuring the continuity of some of the most visible traditions that were introduced by Elijah. The changes in the moment were captured by the restoration of the internal appearance of Mosque Maryam to its original form under Elijah.

\section{IV: Internal Tensions and External Interventions: Prophet or Profit?}

As indicated above, although the court case was mainly about the distribution of the Nation of Islam properties, throughout the process the court had to address many societal, religious and legal questions surrounding the NOI and thus had the opportunity to assess many of the movement's unconventional positions. One of the questions that the court addressed was whether donations to the NOI were the property of the movement or its leader, Elijah. One group argued that the leadership status of Elijah was used in the solicitation of the support donations which were described as being tax exempt and thus meant to support the movement's social services. What complicated the issue however was that donations collected for the poor were used by the movement to invest in different properties and businesses. Consistent with its ideology, the movement wanted to create economic self-sufficiency. Thus, donations of all kinds were meant to be invested in different areas for profits that could then be reinvested into the movement. This framework created the question of if and how a religious group can be for profit, and if so, who would have rightful ownership of the profits?

Under Elijah's leadership, the movement rose from being a small Detroit based movement to one with national prominence. The movement's message resonated with an increasing number of people:

I appeal to all Muslims, and to all the members of the original Black Nation in America, to sacrifice at least five cents from each day's pay to create an "Economic Savings Program" to help fight unemployment, abominable housing, hunger, and nakedness of the 22 million black people here in America who continue to face these problems.

We hope to set up a committee to teach and force our people to be clean: The Committee of Cleanliness. We already have such a committee in effect among the Muslims. It compels our people to clean their bodies as well as their houses... Until we enforce cleanliness among the people of our Nation and get them into the spirit of self-respect and the spirit of making

${ }^{19}$ From the court proceedings, re: Estate of Muhammad, 520 N.E.2d 795 (Ill. App. Ct. 1987) 
70 Transformative Years, Judicial Questions and the Nation of Islam

themselves the equal of other civilized nations of the earth we will never be recognized as being fit members of any decent society of those nations.

Send your quarters every week to Muhammad's Mosque No. 2 in Chicago, Illinois. These quarters will be banked until we have a million dollars to begin building a banking system...

We are asking you to help us enlarge our educational system so that our people can be educated. This we refer to as re-education into the knowledge of self, our history and the knowledge of the good things of life, of which we have been deprived. You can also aid us by subscribing to the Muhammad Speaks Newspaper.

May Allah bless our poor dependent people in America with better homes more money and better friendships among the nations of the earth. (Elijah Muhammad, The Message to the Black Man, 1965) 20

From 1934 to 1975 the movement's membership reached, according to some, 600,000 (based on the distribution of Final Call, though real numbers are always disputed) and the Nation's wealth included many properties including schools in 46 cities, restaurants, stores, a bank, a publishing company that prints the country's largest circulating black newspaper, and 15,000 acres of farmlands in three states that produce beef, eggs, poultry, milk, fruit and vegetables. Due to its personal and economic empowerment theology that tied individuals' empowerment to economic empowerment, the movement combined both profit and non-profit components. The movement's printed invitation for donations indicates how its theology and survival rested on the contributions of others and careful investments by the movement.

The Nation's calls for donations were encouraged as a religious injunction, social solidarity to help to those in need. Yet at some point separate donations were asked with the intention of covering the needs of the movement's leader and his family only. The movement's official solicitation below captures the complexity of the movement by including a carefully selected citation from the Quran (Surah Maryam verse 30-31) that praises both Jesus and charity and appeals to those who are new to Islam, giving an option to contribute to the leader directly and indicating that tax exempt status:

Charity is a principle of Islam second only to payer. Charity is a principle of every religion and we think it should be clearly discussed and understood as every other principle is.

In our life as negroes we are asked to contribute to everything under the sun but you can count on two fingers how many things we contributed to that really helped us to achieve freedom, justice, equality and recognition as a civilized people. In Islam under the divine guidance of the Honorable Elijah Muhammad for the first time we can see the benefits of charity.

Remember that charity wasn't something that was just added to Islam. It is as old as Islam itself and a quotation from the Holy Quran will bear out that all the prophets themselves were subject to the poor rate or charity: Jesus said: "Surely I am a servant of Allah: he has given to me the Book and me a prophet (not his son) and He has made me blessed wherever I may be and He has enjoined on me prayer and poor rate as long as I live" (19: 30-31). Enclosed here is a charity slip. This slip is actually a receipt for whatever moneys you

${ }^{20}$ Elijah Muhammad, The Message to the Black Man, Chicago:Final Call, 1965. 
contribute to the growth of your chosen religion and it is income tax-deductible. You should, therefore, save these slips to substantiate your deduction.

There are several charitable items listed which should have our support: No. 2 Poor: This treasury is for the use of our leader and teacher. With it the Honorable Elijah Muhammad sees to it that the poor and needy of our nation are looked after. This treasury is also designed to see to it that our leader and teacher himself and his family want for nothing. The generosity of our leader is so well known that stories are told about his gifts throughout the Nation. For a man who has given his very soul and health to see to it that his people hear the truth, we cannot give too much. ${ }^{21}$

As the above text used by the movement shows it carefully situated itself at the intersection of Abrahamic faiths. Referring to the Quran where Jesus was mentioned appealed to the sensibilities of those who were new or old to Islam and had upbringing in different faiths. The intricate language used it the Nation's calls for contributions was not discursive. In fact, the Nation of Islam created an institutional framework that corresponded to the distinct parts of its ideology and included three parts:

- Poor Funds-- captured the movement's charity side and received donations

- Progressive Land Developers Inc. --captured movement's business side that sought to strengthen the movement's financial capacity through economic activities

- Temples-captures the movement's religious services

In order to under to understand Elijah's role in maintaining these three parts it is important to recognize the various roles assigned to his carefully crafted personality. The Nation's Orientation Brochure captures how Elijah's role was introduced to new members in terms that evoked the various roles of a civil rights activist or leader, a holy- person or a religious leader simultaneously:

The messenger has been a solitary man fighting for his ideas and principles but he has never become discouraged or embittered for his eloquence, wisdom and inspirations are derived from the triumphant Lord of the Worlds-ALLAH. Today the Honorable Elijah Muhammad stands alone as the unacclaimed leader of the American Negro and the beloved leader of we who follow him. In those of us who know him intimately he has inspired loyalty, given meaning to our lives, and articulated our aspirations for a "UNITED FRONT OF BLACK MEN." To us he is indeed an Anointed leader.

The messenger is a remarkable person, though he is the most self-effacing and modest of public men. He has lived and suffered in the midst of the hurly-burly of the American Negro's problems, and knows the hopes and aspirations of his people exceedingly well. Our leader and teacher is totally free from scheming and duplicity, honest to enemy and friend alike. For him we will lay down our lives. We swear allegiance to no other leader or combination of leaders.

${ }^{21}$ From the exhibition material of Estate of Muhammed, 463 N.E.2d 732 Ill. App. Ct. 1984. 
Remember that! (Orientation Brochure) ${ }^{22}$

Although the court expected the movement's three parts (the charity, the investment and temple/religious services) to be clearly distinguished and managed, these three components were not separated, particularly during the early years of the movement. While the court described the lack of separation among the movement's different parts as "co-mingling", what was neglected was that the failure of the movement to separate its profit side from its non-profit side was due to its theological and social commitments. It is important to note that the establishment and emergence of the movement coincided with the creation of the modern tax system in the US which regulated the declaration of non-profit status. The movement developed as the regulatory terrain was changing to meet new challenges and demands. ${ }^{23}$

\section{Turning Points: Quests for Legitimacy and Unexpected Trajectories}

Throughout its history, the Nation had always moved on two separate, yet intertwined, tracks in terms of its relationship with mainstream society and its rules and expectations. The nation described itself as "a nation within a nation," and carried with it a strong anti-establishment discourse while simultaneously choosing to operate within the parameters made acceptable by the legal and judicial system. In contrast to, or perhaps because of, the discourse that often described the Nation as illegitimate, the movement's discursive practices have carefully pushed the boundaries yet remained within the systemic boundaries. For instance, although the movement rejected the "draft," it opted for civil disobedience to protest the war/conscription, and accepted jail sentences for such actions. It sought legitimacy according to the standards laid out by the system it critiqued so vociferously, but that legitimacy always came with costs and new complications. Additionally, the legitimacy was coming from the institutions of a system whose legitimacy the members themselves questioned.

Beyond the surface of its highly contentious and polarizing language, the movement had a rather unexpected outlook that made inroads to its formal policies. For instance, although the nation adopted a strong anti-systemic language, it also sought to operate within the system and acquire legitimacy through multiple avenues. Given its multi-faceted appeal as a race, social-welfare, rights and religious movement, the movement's language has lent itself to different and contradictory interpretations. Perhaps due to diverse interpretations, some notes clearly stated that the movement did not challenge or denounce existing policies confronted as a movement.

For instance, in its solicitation for donations, the Nation's note included the following:

“This [the nation's efforts] will not interfere with, the government's program for better housing conditions at all; it will only aid those who have never known anything in the way of help and those who do not even know that there is a government housing act to help dependent people. There are thousands of our people living in worse conditions than dogs and pigs. At least dogs are not bothered with too many rats and roaches in their houses because they kill them to keep out the uncleanliness and filth which dominate and create bad housing conditions." 24

\footnotetext{
${ }^{22}$ From the exhibition material of Estate of Muhammed, 463 N.E.2d 732 Ill. App. Ct. 1984.

${ }^{23}$ Paul Arnsberger, Melissa Ludlum, Margaret Riley, and Mark Stanton, “A History of the Tax-Exempt Sector: An SOI Perspective," Statistics of Income Bulletin, Winter 2008.

${ }^{24}$ From the exhibition material of Estate of Muhammed, 463 N.E.2d 732 Ill. App. Ct. 1984.
} 
The tone of the announcement above was not exceptional. Despite the movement's sharp denouncements of the "white" establishment for putting shackles on the black community it still accepted the state's policies and powers. The movement declared many times it sought not to undermine but to improve the living conditions of its followers by building upon existing programs and filling the needs not adequately addressed by the state. It is not surprising therefore, that considering itself a religious group working in the name of public interest, the movement tried to acquire tax-exempt status for its temples and started its businesses by following acceptable business practices. Elijah's letter to his lawyers captures the movement's dual discourse that conveys distrust and seeks to gain legitimacy at the same time. It captures the movement's conviction that it would not be granted this status due to the social and political biases against it. Yet, instead of denouncing the tax policies, the movement declared its commitment to maintain its legitimacy at the expense of paying more in taxes. A letter typed by Elijah on February 1, 1971 to the movement's lawyer Newton Brozan based in New York indicated the Nation's overall sentiment about the movement's treatment:

Thank you for your letter of January 8, 1971. Let us forget about this tax appeal for exemption. The government is not, by any means, willing to show me and my followers any favor. This, I am well aware of, and will not try again; even if takes half our income to pay tax, we will pay it.

Thank you for your efforts that you have made over a year. I appreciate it. Please send me your bill for what you have been trying to do in the way of getting us tax exemption.

Sincerely Elijah Muhammad 25

Although the ultimate goal of economic separation was declared, one of the appeals of the movement has been its insistence on economic empowerment as inherent to political and spiritual independence. Thus, although the Poor Funds (the charity aspect of the movement) and Progressive Funds (investment side of the movement) are seen as contradictory by others, for the movement they were necessarily related projects. Given the complicated nature of the movement, the court consistently tried to determine if the nation of Islam was a religion (thus its property needed to be inherited by the movement), or a private venture or organization under the leadership of Elijah. Facing the various components of the Nation, the following excerpt from the court proceedings offers an example of how the court sought to make sense of the identity of the movement and reflected on one definition of the movement as a religious organization:

Court: To be honest it was more than a religious organization.

Mr. Heinz: Certainly was. I can see that

Court: That's where we have a problem because if we merely say that the Nation of Islam is a just religious organization we are not being accurate.

Mr. Heinz: I can see that it was more than religious organization your Honor. 
Court: Because as he has indicated in the orientation brochure and all of the evidence indicated the nation of Islam really was a nation within a nation, intended to create a nation composed of black people. ${ }^{26}$

The exchange above, and other similar lines of questions, dominated the court's questions and that "nation within a nation" concept was suggested by Judge Budzinski as the working definition of NOI without answering any of the questions about what "religious organization plus" meant institutionally and legally. For instance, would Nation of Islam INC. be considered as an organic expansion of the movement due to its theology and goals? Devoid of a thorough review of the movement's theology, perhaps it's not surprising that the circuit and appellate courts delivered four distinct decisions declaring the movement a private organization and a religion.

Although its policies were contentious, the Nation's efforts were officially recognized by Mayor Richard J. Daley and Governor Dan Walker. In fact, the last Savior Dinner (a yearly traditional dinner for the movement) held before Elijah Muhammad's death, was endorsed by official representatives of the Mayor and Governor and participation was encouraged to raise funds for the movement's Southside hospital project. ${ }^{27}$ That recognition continues to be an important part of the movement's discourse especially when its legitimacy is questioned. Along with its motto "we turn boys to men", the movement presents it mission as creating model US citizens. In fact, Elijah described his followers:

"Despite the unfavorable attitude of those in power (Government) toward my followers, I must emphatically deny their being "subversive" in any way or manner whatsoever. How could anyone expect trouble of any kind from a peace-loving people who aren't even allowed to carry a pen-knife on them at any time? My followers, in fact, are the BEST CITIZENS this country has got, because they are believers in Islam, the Religion of Peace, and in Righteousness, not evil, and they can do no wrong to anyone." 28

Although the followers of the Nation might be defiant, Elijah Muhammad argued, they remain defiant within the boundaries of the law.

\section{Conclusion}

The sudden rise of the Nation from the preaching of two individuals, Ward (1929-1934) and later Elijah (1934-1975), to an organization with national prominence came with many theological adaptations and organizational challenges. Due to its theology, the nation focused both on spiritual and economic independence, and did not see any difference between the two. Although its theology was anti-systemic, it consistently sought to legitimize itself through carving out a place in the market system and developing a theologically hybrid language. In its theology, the movement combined the tenets from (i) orthodox (universal) Islamic claims (which denounce any discrimination based on race) and (ii) racialized discourse that claims the root of black problems is the internalization of the slave mentality and lost sense of the self and the original status. Due to the fact that economic

${ }^{26}$ ibid

${ }^{27}$ Chicago Tribune, No Elijah but Dinner is a Success, March 3,1974.

${ }^{28}$ Elijah, Muhammad. (1957) The supreme wisdom: solution to the so-called Negroes problem. Newport News, VA ; National Newport News. 
empowerment is inherent to its theological empowerment, The NOI did not fit any institutional template (non-profit vs. profit, organization vs. religion) that typically helps guide judicial decisions.

The Nation of Islam's trial posed the question of if and when a group is considered as religious. Given the Supreme Court's decisions on religion one might ask if and how the court defined its own criteria of what it means to be a religious group. For instance, in the United States v. Seeger (1965) the court treated any beliefs as religious if a given belief was sincere and meaningful and occupied a similar place in the life of its possessor parallel to that filled by the orthodox belief in God. ${ }^{29}$ In Welsh v. United States (1970) the court let followers say the final word by describing religion as "deeply and sincerely held moral and ethical beliefs" and thus granting those groups holding such beliefs the status of religious. ${ }^{30}$ The court's decision to treat Elijah Muhammad's properties as his personal property suggests that the court gave more weight to the claims that reduced the nation to a private venture; whether the supporters treated the group as religious or the nation considered itself a religion did not change the result.

Although the Nation of Islam's theology remains controversial and it is often assessed in a vacuum, it is important to notice that since its inception the movement has incorporated some monotheistic, Abrahamic religious beliefs as well as non-monotheistic ideas from its immediate intellectual environment. Self-reliance and emancipation against historical and present injustices took priority over religious puritanism. Given its hybrid theology and organizational structure, the lower court's decision to redistribute the Nation's wealth resulted in the overall decline in its organizational capacity and the dominance of one branch over the other. The decision also reinforced the impact of the well entrenched dichotomies or markers that rendered the movement as an anti-systemic fringe group. The court decision confirmed that the movement fell in a gray area left by the boundaries drawn by the binaries of Religion vs. Cult, Native vs. Migrant, City vs. Colony, Separatist vs Integrationist. While the movement's financial success raised many questions about the proper uses of funds, the nation's projects took many distinct forms.

It is important to note that two years prior to the beginning of its court case, the Nation was soliciting funds to complete its south-side Chicago project. Due to the impact and necessity of such a project, the nation garnered a wide range of support. As noted above, the 1974 Savior Day was recognized by the city's mayor and all residents were invited to support the nation's efforts. Such endorsements were based on the Nation's practices and its social projects, especially its Southside Chicago Hospital. Not only did such projects become defunct due to the redistribution of the funds but also the movement lost its social appeal. Given the decline in the movement's branch that sought to promote a more inclusive theology, one might argue that the court decision both reflected the corrosive social image of the Nation (e.g., cult promoting private profit) held by some in the 'mainstream' and served as a block thwarting the movement's development as a more inclusive and universal social movement working to better the lives of a marginalized community. Such an assessment indicates that instead of viewing unconventional movements like the Nation as in tension with the state, we might see them as the output of some state policies. In other words, neither the Nation's emergence nor the decline in its power after the early 1980s is a process beyond the societal and state dynamics; instead they are the outcome of the negotiations between the state and multiple actors that came to speak on behalf of the Nation with different outcomes.

\footnotetext{
${ }^{29}$ United States v. Seeger, 380 U.S. 163 (1965) United States v. Seeger, No. 50 March 8, 1965 (380 U.S. 163).

${ }^{30}$ Welsh v. United States (No. 76) January 20, 1970 (398 U.S.333)
} 


\section{References}

Carter, Shawn. 2002, 'The Economic Philosophy of Marcus Garvey', Western Journal Of Black Studies, 26:1.

Dagnini, Jérémie Kroubo. 2008. "Marcus Garvey: A Controversial Figure in the History of Pan-Africanism." Journal Of Pan African Studies 2, no. 3: 198-208.

Deen Warith, "The Lost-Found Nation," The Bilalian News, Vol.1, no.1 November 14, 1975.

Erdmann Doane Beynon, "The Voodoo Cult Among Negro Migrants in Detroit," American Journal of Sociology. Vol. 43 (July 1937 - May 1938). Pp. 894-907.

Grant, C. Negro with a Hat: The Rise and Fall of Marcus Garvey. Oxford University Press, 2008.

Hughes, Frank. 1943. "Experts Trace Race Conflicts To Dixie Exodus.” Chicago Tribune.

Jalal, A. 2005. Self and Sovereignty: Individual and Community in South Asian Islam since 1850. London: Routledge.

Johnson, Sylvester A. 2010. "The Rise of Black Ethnics: The Ethnic Turn in African American Religions, 19161945." Religion \& American Culture 20, no. 2: 125-163

Jones, Elias F. "Black Hebrews: The Quest for Authentic Identity." The Journal of Religious Thought, vol. 44, no. 2, 1988 , pp. 35.

Mubashshir, Debra Washington. 2001. "Forgotten Fruit of the City: Chicago and the Moorish Science Temple of America." Cross Currents 51, no. 1: 6

Muhammad, Elijah. 1957. The Supreme Wisdom: Solution to the So-Called Negroes Problem. Newport News, VA; National Newport News.

Elijah Muhammad, 1965. The Message to the Black Man, Chicago:Final Call.

Murphy, E. 2016. From Sufism to Ahmadiyya: a Muslim minority movement in South Asia. Contemporary South Asia, 24(2), 214-215.

Nance, Susan. 2002. "Respectability and Representation: The Moorish Science Temple, Morocco, and Black Public Culture in 1920s Chicago." American Quarterly 54, no. 4: 623.

Nipson, Herb. 1961. “Astute Study of a Hate Group”. Chicago Tribune. May 15.

Page, Clarence. 1974. "No Elijah but Dinner is a Success." Chicago Tribune. March 3.

United States v. Seeger, 1965. 380 U.S. 163

Vardat, Scott J. 2013. "Drew Ali And The Moorish Science Temple Of America: A Minor Rhetoric Of Black

Nationalism." Rhetoric \& Public Affairs 16, no. 4: 685-717.

Walter, H. A. 1918. The Ahmadiya Movement. Oxford University Press.

Welsh v. United States, 1970.398 U.S. 333

Williams, Armstrong. 2015. "The Nation of Islam Could Be Chicago's Saviour.” The Hill. October 5.

Wynia, Elly. 1994. The Church of God and Saints of Christ: The Rise of Black Jews. Milton Park: Taylor and Francis. 